\title{
ÖZENGEN MÜZIK EĞiTiMi VEREN KURUMLARDA TÜRK MÜZiĞi iLGisi: MALATYA ÖRNEĞi
}

\author{
Ünal IMiK¹ , Yağmur Eylül DÖNMEZ \\ *Inönü Üniversitesi Devlet Konservatuvarı Müzik Bölümü / Malatya
}

\begin{abstract}
Özet
İnsanoğlu, duygularını ifade ederken, sanat olarak adlandırdığımız çok çeşitli anlatım biçimlerini kullana gelmiştir. Müzik sanatı da, bu ifade biçimlerinin en çok tercih edilenlerinden biri olmuştur. Bu sebepledir ki, müzik yapabilme yeteneği bu alana ilgi duyan bireylerin vazgeçilmez bir arzusu durumundadır. Bu durum, mesleki müzik eğitimi veren kurumlarının yanı sıra konuya ilgi duyan bireylerin özengen müzik eğitimi fırsatı bulabileceği çeşitli kurumların mevcudiyetine de zemin hazırlamıştır. Araştırmanın amacı, Türk müziğine yönelik ilginin özengen müzik eğitimi kurumlarındaki düzeyini çeşitli yönleriyle Malatya örnekleminde sorgulamaktır. Araştırma betimsel bir özellik sergilemektedir. Bu sebeple verilerin toplanması aşamasında betimsel araştırma tekniklerinden faydalanılmıştır. Konu ile ilgili olarak Malatya Büyükşehir, Battalgazi ve Yeşilyurt Belediyeleri bünyesinde faaliyet yürüten sanat merkezleri ile merkez ilçelerde bulunan çeşitli cemiyet, dernek ve özel kurs merkezleri incelenmiştir. Araştırma sonuçlarında bazıları sıralanacak olursa; özengen müzik eğitimi kurumlarında Türk müziğine yönelik olumlu yönde belirgin bir talep olduğu, hemen her sanat merkezinde mutlaka Türk müziği alanında çalgı ve ses eğitimi derslerine rastlandığı, özellikle bağlama çalgısının bu manada diğer çalgılara göre daha yoğun talep gördüğü, Türk müziğine yaş ve cinsiyet ayrımı yapılmaksızın toplumun her tabakasından ilgi gösterildiği ilk aklımıza gelenlerden birkaçı olacaktır.
\end{abstract}

Anahtar Kelimeler: Müzik, Eğitim, Türk Müziği.

\section{TURKISH MUSIC INTEREST IN THE INSTITUTIONS GIVING MUSIC EDUCATION: THE EXAMPLE OF MALATYA}

\begin{abstract}
Mankind has used a variety of forms of expression, which we call art, as a means of conveying their emotions. Music art has also become one of the most preferred of these forms of expression. This is why the ability to make music is an indispensable desire for individuals interested in this field. This situation has created a foundation for the existence of various institutions that can find the opportunity of private music education for individuals who are interested in the subject as well as institutions providing professional music education. The aim of the research is to question the level of the Turkish Music Relation
\end{abstract}

\footnotetext{
${ }^{1}$ Yazışma yapılacak yazar: unal.imik@inonu.edu.tr
} 
in the private music education institutions in the sample of Malatya with various aspects. Research is descriptive. For this reason, descriptive research techniques have been utilized during the collection of data. In relation to the subject, the art centers that operate in the municipalities of Malatya, Battalgazi and Yeşilyurt, as well as various community, association and private course centers located in the central districts have been examined. If some of the research results are listed; there is a clear demand in the positive direction towards Turkish music in music education institutions that there are absolutely no lessons in the field of music and instrument education in the field of Turkish music and especially in the context of the connection music is more demanding than other instruments in this regard, will be a few of the first ones to show interest in the layer.

Keywords: Music, Education, Turkish Music.

\section{GíRiş}

Tarihi süreçler incelendiğinde, Türk halkının yazılı kültür aktarımından ziyade sözlü kültür aktarımını tercih ettiği görülmektedir. Bu sebeple halkımıza ait müzik ürünleri, sosyo-kültürel hayatımızın hemen her aşamasında vazgeçilmez bir öneme sahip olmuştur. Özellikle, halkın gündelik yaşamında ifade etmek istediği duygu yoğunluğu müzik ürünlerinde kendine önemli bir yer bulmuştur. Mutluluk, hüzün, heyecan, sevinç ve daha birçok duygu mani, destan ve türkü gibi sözlü formlara dökülmüş ve bu yolla karakteristik kültür öğelerimiz bir sonraki kuşaklara da aksetmiştir. Bu yüzdendir ki, Türk müziği sadece bir müziksel etkinlik olarak görülmemeli ve bünyesinde barındırdığı derin mana ve ifade özellikleri yeterli düzeyde anlaşılmalıdır. Özellikle genç kuşakların Türk müziğine ilgi duyması ve Türk müziğini anlamaya fırsat bulması her yönü ile desteklenmelidir. Bu noktada toplumu meydana getiren genç bireylerin Türk müziği eğitimi konusunda çeşitli özengen müzik eğitimi verilen merkezlere yönlenmesi oldukça olumlu bir gelişme olarak görülmelidir.

Eğitim kavramına yönelik birçok farklı tanım mevcuttur. Bunlardan bazılarına göz atılacak olursa: Bloom'e göre eğitim, kişinin davranışlarında, kendi yaşantıları yolu ile istendik yönde ve bir dereceye kadar kalıcı değişmeler meydana getirme süreci olarak tanımlanır, ürün olarak ele alındığında bu süreç sonunda oluşan davranış değişmeleri bütünüdür (Bloom, 1979: 300). Akyüz'e göre eğitim, Kişinin zihni, bedeni, duygusal, toplumsal yeteneklerinin, davranışlarının en uygun şekilde ya da istenilen bir doğrultuda geliştirilmesi, ona bir takım amaçlara dönük yeni yetenekler, davranışlar, bilgiler kazandırılması yolundaki çalışmaların tümüdür. Eğitim, hayat boyu sürer; planlı ya da tesadüfi olabilir. Okul, okuma-yazma, ders araç gereçleri ile ve bunların dışında aile veya çevre içinde, kişisel yetişme vs. yollarıyla yapılan öğretme, öğrenme, bilgi aktarma, beceri kazandırma çalışmalarının tümünü kapsayan bu çabalara yaygın eğitim de denmektedir. Kısaca, eğitim, öğretimi de içine alan çok geniş bir terimdir” (Akyüz, 2006: 2). Özsoy’a göre eğitim, bir toplumun yeniliklere ve uygarlığa ayak uydurmasının en önemli araçlarından biridir. Bireyin kendini ifade etmesinin sağlanmasında eğitimin rolü tartışılmazdır. Eğitim insana yapılan uzun vadeli bir yatırımdır. Bu nedenle eğitim çok doğru planlanmalı, amaçları çok iyi saptanmalıdır (Özsoy, 2003: 25). Uçan'a göre eğitim, "Bireyleri ve toplumları biçimlendirme, yönlendirme, değiştirme, geliştirme ve yetkinleştirmede en etkili süreçtir. Eğitimle bireylerin bedensel, devinişsel, duyuşsal ve bilişsel yapılarıyla/yönleriyle dengeli birer bütün 
halinde en uygun ve ileri düzeyde yetiştirilmeleri amaçlanır" (Uçan, 1997: 59-60). Ertürk'e göre eğitim, "Bireyin davranışlarında kendi yaşantısı yoluyla ve kasıtlı olarak istendik değişme meydana getirme sürecidir" (Ertürk, 1972: 12).

Tanımlar ışığında söylenebilir ki eğitim; insanoğlunun doğduğu andan itibaren başlayan ve yaşam boyu devam eden bir süreç ise; birey bu süreçte diğer bireylerden elde etmiş olduğu yaşantıları kullanarak hayatını devam ettirme olanağı bulacaktır. Ve elde etmiş olduğu yaşantılar yoluyla davranışlarında değişmeler meydana gelecektir. Bu yolla birey çocukluk, gençlik ve yetişkinlik dönemlerine göre bilgi, beceri, tutum ve değerleri elde ederek yaşamını sürdürmesi olasıdır.

\subsection{Sanat}

Sanat kavramı, yapısı ve kapsamı itibarı ile oldukça büyülü bir kelimedir. İnsanoğlu duyu organlarımıza hoş gelen ve oluşumunda yetenek gerektiren birçok unsura sanat yakıştırması yapmıştır. Bu sebeple sanat kavramı ile beraber anılan hemen her şey, beğeni ve takdir toplayan bir konumda olmuştur.

Sanat kavramına yönelik birçok tespit ve tanım yapılmıştır. Sanat, Uçan'a göre; dünyanın karmaşasından uzaklaşabilmenin bir yoludur. Sanat, bir terapidir, ruhu aydınlatır. Sanat, ekonomi, siyaset, sosyoloji gibi birçok alanda bilgiler ve göndermeler içeren bir başkaldırıdır. Sanat, insanın kendine ve çevresine karşı gerçekleştirdiği bir eleştiridir. Sanat, yaratıcı bir süreç, bir iletişim ve bir anlatımdır. Sanat, bireyin kendine özgü bir kişilik kazanmasını, sağlıkı, başarılı, duyarlı ve mutlu olmasını sağlayan bir araçtır. Toplumlar arasındaki iletişim ve etkileşimde, paylaşmalarda, bütünleşmelerde sanatın rolü yadsınamaz derecede önemlidir. Sanatın insan sağlığı üzerindeki ve toplumlar arasındaki bağı güçlendirici etkisinin yanı sıra kültürel kimlik sağlamak gibi çok önemli bir işlevi daha bulunmaktadır (Uçan, 1996: 123-125). Finkelsteinê göre sanat, yaşamın dertlerinden bir kaçış yolu ve zihnin hiç bilmediği gizemli düşüncelere uyanışının verdiği bir coşkudur. Sanat, bireylere öğrenme hazzını yaşatmaktadır (Finkelstein. 2000: 9). Webern'e göre ise; "Sanat, genel olarak doğanın, özelde insanın doğası biçimi altındaki bir ürünüdür" (Webern. 1998: 20).

Eflatun (Platon) sanatı bir kopyayı tekrar kopya etmek ya da bir imgeyi tekrar imgelemek olarak tanımlarken, sanatın bir yansıtma olduğunu vurgulamıştır. Ona göre sanatçı, gerçekten uzaklaşan bir kişidir. Eflatun'un öğrencisi olan Aristo'ya göre ise sanatçı insanlara hayatı açıklayan bir kişidir. Eflatunun duyu dünyasının dışında var olduğunu söylediği idealar aslında duyu dünyasındadır ve Aristo'ya göre sanat, insan eliyle doğanın başlamış olduğu şeyi tamamlamaktır. Herbert Read'e göre sanat bir anlatım ve bilgi tarzıdır (Özsoy, 2007: 22-23). Birçok ünlü düşünür, kıymetli yazar ve bilim insanının görüşleri dikkate alındığında kısaca sanat, duygu ve düşüncelerimizin müzik, dans, resim, heykel, mimari, opera, bale, tiyatro vb. ifade biçimlerine dönüşmüş halidir. 


\subsection{Sanat Eğitimi}

Sanat ve eğitim kelimelerinin bir araya gelmesiyle oluşan "sanat eğitimi" terimi iki kelimenin birleşmesi ile kolaylıkla yazılabilse de, uygulamada aşamasında oldukça meşakkatli ve uzun bir süreç gerektirmektedir. Eğitimin ne denli titiz ve dikkatle planlanması gereken bir süreç olduğu düşünüldüğünde buna bir de sanat gibi yetenek unsurunu barındıran bir kavramın eklenmesiyle oldukça hassas ve ciddi çalışma prensibi gerektiren bir yapı ile karşılaşılmaktadır. Sanat eğitimi öncelikle bireyin psikolojik olarak birçok yönden (arzu, disiplin, sabır, özveri, vb.) buna hazır olması ile mümkün olabilir. Sadece bunun yetmediği gibi gerekli ortam koşulları ve eğitimi sürecinde kullanılacak donanımın da hazır olmasına intiyaç duyulmaktadır. Bu konuda yapılan çeşitli tanım ve yorumlar incelenecek olursa:

Uçan'a göre sanat eğitimi; "bireye kendi yaşantısı yoluyla amaçı olarak belirli sanatsal davranışlar kazandırma ya da bireyin sanatsal davranışında kendi yaşantısı yoluyla amaçı olarak belirli değişiklikler oluşturma sürecidir" (Uçan, 1996: 125). Ersoy’a göre sanat eğitimi; bireyleri estetik bir düzeye ulaştırmak, yaratıcılıklarını ve özgün dışavurumlarını ortaya koymalarını sağlamak üzere hoşgörülü bir ortamda gerçekleştirilmeye çalışılan eğitim çabalarının bütünüdür (Ersoy, 1985: 57-58).

Sanat eğitimi sürecinden geçen birey, çok yönlü düşünmeyi öğrenir. Problemlere farklı ve özgün çözüm arayışları bulmaya çalışır. Çünkü sanat eğitimi kişilerin özgürce kendilerini ifade etmelerini sağlayabilir ve belki de farkında olmadan kişi, çözümü düşünen bir birey olma yolunda yürümeye başlar.

Gençaydın ve Doğan'a göre; sanat eğitimi, toplumların kalkınmasında itici bir güçtür. Endüstri ve bilime yapılan yatırımların verimliliği ancak nitelikli, ülke sorunlarına karşı duyarı işgücü ile sağlanabilir. Bir duygu ve akıl varlığı olan insanın ruhsal doyumu için duyarlılığın geliştirilmesi gerekmektedir. Duyguları, estetik değerlerin hazzıyla beslenen insan kötülük düşünemez. Duyarlıı̆ı̆ı kazandııılmasının en kolay yolu sanat eğitimidir. Bu anlamda "bilgisiz toplumlar cahil, ama duyarsız toplumlar barbardır". Sanat eğitimi, bireyin çevresine karşı duyarlı ve hoşgörülü olmasını, bilgi ile donatımasını, yararlı bir uğraş alanı kazanmasını sağlayacaktır (Gençaydın, 2002: 29; Doğan, 2002: 125). Bahsi geçen bireysel özelliklerin birkaçının dahi bir arada olması insan yaşantısında oldukça önemli bir erdem seviyesi olarak görülebilir.

Kırışoğlu'na göre; "sanat eğitimi, eğitim ve sanatın değişik konumlarda, değişik boyutta ve ağırlıkta bir araya geldiği bir alandır. Çevreyle ilk tanışma, görme, algılama, adlandırma ve düzenleme ile başlayan sanat eğitimi daha sonra ürün verme, üründen tat alma olarak gelişir. Okul düzeyinde ise sanatsal bilgi ve deneyimin çocuğa, gence, yetişkine belirli bir düzen içinde, kazandırdığı bir disiplin alanı olur. Burada artık sanat, ürünü, tarihi, eleştirisi ve estetiği ile öğretilen ve öğrenilen bir ders olma durumundadır" (Kırışoğlu, 1991:104).

Sanat eğitimi, "genel sanat eğitimi", "özengen sanat eğitimi" ve "mesleki sanat eğitimi" olmak üzere, üç ana amaca yönelik olarak gerçekleştirilmektedir. Genel sanat eğitimi, her düzeyde ve herkes için gereken asgari 
düzeydeki sanatsal kültürlenme süreci olarak görülmelidir. Bir diğer sanat eğitimi süreci olan özengen sanat eğitimi ise, sanata karşı amatörce ilgi duyan bireylere bu davranışlarını geliştirmek üzere gerekli sanatsal davranışlar kazandırmayı amaçlayan bir süreç olarak ifade edilebilir. Mesleki sanat eğitimi ise, sanat ile ilgili bir dalı, konu alanını ya da bütününü bir meslek olarak seçen, seçmek isteyen kişilere yönelik mesleğin gerektirdiği sanatsal davranışları ve birikimi kazandırmayı amaçlayan bir eğitim sürecidir (Uçan, 1996: 125128). Bunlardan özengen sanat eğitimi, içerisinde barındırdığı amatör yaklaşımla belki de en istekli ve keyifli eğitim süreçlerinden biridir.

\section{3. Özengen Müzik Eğitimi}

Özengen müzik eğitimi; bireylerin, ilgi ve istekleri doğrultusunda, yetenekleri ne olursa olsun bir zevki ve tatmini amaçlayan, bulundukları seviyeyi de ileriye taşımalarını hedefleyen bir müzik eğitim türüdür (Ürün, 2015:8). Özengen müzik eğitimi içerisinde barındırdığı amatör ruh ve yaklaşım sayesinde oldukça keyifli bir hobi faaliyeti şeklinde başlar.

Amatör, Latince amo (aşk) kelimesinden türemiştir. Gerçek anlamıyla amatör müzisyen, müziğe sevgiyle bağlanmış kişi demektir. Ancak yaygın kullanımı bu anlamından farklıdır. Amatör müzisyenlerin kökeni Rönesans dönemine kadar uzanmaktadır. Rönesans döneminde amatör ve profesyonel müzisyenler arasındaki fark çok belirgin değildir. Profesyoneller müzikle yaşarken, genellikle aristokrat sınıfa mensup amatör müzisyenler müziği zevk için yapmış ve zaman zaman iyi bir eğitim ile profesyonel müzisyenlerin becerilerini geçmişlerdir. Tarihte, Kral David, şarkıcı ve lir çalıcısı, Büyük Frederic flütçü, Thomas Jefferson kemancıdır (Deverich, 2006: 2). Tarihimiz incelenecek olursa Dede Korkut'tan günümüze Türk hükümdarlarının da müzik alanında çeşitli bestecilik, icracılık ve nazari özellikleri sergiledikleri görülecektir. Sultan III. Selim Han, Sulan I. Mahmut Han ve Sultan Abdülaziz Han bunlara birer örnektir ve bu örnekleri çoğaltmak mümkündür.

Özengen (amatör) müzik eğitimi, öğrenmeye istekli olan bireylere zevk ve doyum sağlamak için gerekli müziksel davranışları kazandırmayı amaçlamaktadır. Herhangi bir düzeyde olabilir ve seçmelidir. Örgün eğitim içinde, eğitsel kol çalışmaları ile seçmeli ses ve çalgı toplulukları ile bireysel ve toplu müzik kursları ile gerçekleşir. Yaygın eğitimde ise özel kuruluşların düzenledikleri kurslar, özel dersler, konserler, festivaller, yarışmalar özengen eğitim için oldukça önemli bir yere sahiptir (Uçan, 2005: 127). Özengen müzik eğitimi, hem gerekli müzik eğitimini tamamlamak hem de bireylerin çalışma yoğunluğunun getirebileceği stres yükünü azaltabilecek bir alan olarak da düşünülebilir.

\section{4. Özengen Çalgı Eğitimi}

Müzik eğitimi her ne kadar nazari bazı özellikler sergiliyor olsa da, bu konuda bireylerin ilk aklına gelen, bir müzik aleti çalmak ya da şarkı söylemektir. Toplum içerisinde özellikle bir müzik aleti çalabilme konusunda oldukça istekli olan büyük bir kitlenin varığı da yapılan bazı araştırmalarda (İmik, 2007: 65) tespit edilmiştir. 
Bu sebeple, müzik eğitimi sürecinde çalgı eğitiminin oldukça önemli bir basamağı teşkil ettiği söylenebilir. Çalgı eğitimi, öğrencilerin müziksel yaşantılarını biçimlendirmekte, onlara müziksel bilgi, beceri, yetenek ve zevklerini geliştirme olanağı vermektedir (Akbulut, 1999: 511). "Psiko-motor davranışların birbirleriyle uyumlu, hızlı ve otomatik yapılmış şekline beceri denmektedir." Beceriler belli amaçla, belli sırayla ve belli bir süreçte kazandırılması öngörülen kas faaliyetleridir (Akbulut, 1999: 511). Çalgı öğreniminde bilgi ve beceriye büyük intiyaç duyulmaktadır.

Günümüzde çalgı öğrenimi özellikle ülkemizin büyük şehirlerinde oldukça yaygınlaşmış ve ilgi çeken bir durumdadır. Bu konuya ilgi duyan özengen müzik severler bir çalgı çalma isteğiyle çeşitli resmi ya da özel müzik eğitimi merkezlerine müracaat etmekte ve kendilerine uygun bir çalgıyı öğrenme sürecine ilk adımı atmaktadırlar. Bu ilgi bazı durumlarda profesyonel müzisyenliğe kadar uzanabilirken bazı durumlarda ise, gerek ekonomik gerekse sosyo-kültürel sebeplerle kısa sürede sona ermektedir.

Özengen çalgı eğitiminde eğitimcinin yaklaşımı da oldukça önemlidir. Konuya ilgi duyan bireye dikkatle yaklaşması gereken çalgı eğitimcisi, bireyin ihtiyaç duyduğu dersin süresini, sıklığını, zorluk derecesini ve daha birçok özelliğini özenle seçmelidir. Belirlenen ders programı ve niteliğinin bireye uygun olmadığı durumlarda eğitimi sürecinin devamının sağlanması zor bir hal alabilmektedir.

\section{Yöntem}

Araştırma, özengen müzik eğitimi veren kurumlardaki Türk Müziği Illgisini "Malatya" örnekleminde çeşitli yönleriyle incelemeyi amaçlamaktadır. Araştırmanın evrenini Türkiye'de Türk Müziği eğitimi veren özengen kurumlar, örneklemini ise Malatya' da özengen Türk Müziği eğitimi veren kurumlar oluşturmaktadır. Araştırma sürecinde Malatya Büyükşehir, Battalgazi ve Yeşilyurt Belediyeleri bünyesinde faaliyet yürüten sanat merkezleri ile merkez ilçelerde bulunan çeşitli cemiyetler ve özel kurs merkezleri incelenmiştir. Araştırmanın veri toplama aşamasında örneklemlerle çoktan seçmeli ve yarı yapılandırılmış görüşmeler yapılarak 290 katıımcıdan geri dönüt alınmıştır. Özengen müzik eğitim merkezlerinin yönetici ve eğitmenlerine yönelik tespitlerde yapılandııımamış bireysel görüşmelerden faydalanıımıştır. Araştırma sürecinde elde edilen bulgular, kolaylıkla ifade edilebilmesi bakımından görsel grafiklere dönüştürülmüştür.

\section{Bulgular ve Yorum}

Araştırmanın bu bölümde mevcut bulgular doğrultusunda çeşitli yorumlar yapılmakta ve bu yolla konuya yönelik sonuçlara ulaşılması amaçlanmaktadır.

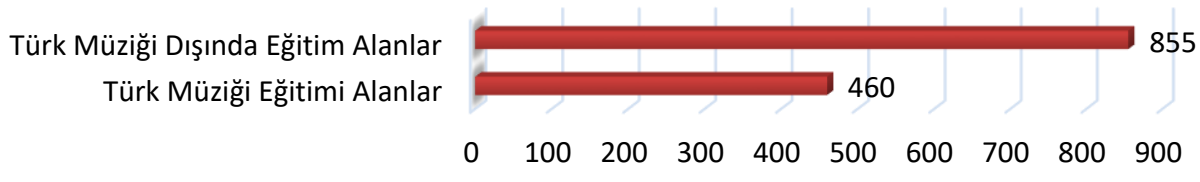

Grafik 1. Türk Müziğine Genel İlgi Durumu

Türk müziğine yönelik tercih durumunun sorgulandığı grafik 1 incelendiğinde; Malatya il merkez ilçesinde '1335' kişinin özengen müzik eğitimi aldığını ve bunların $1 / 3$ oranındaki bölümünün özengen müzik 
eğitiminde Türk müziğini tercih ettiği belirlenmiştir. Bu durum özengen müzik eğitimi alan her üç kişiden birinin Türk müziğine yönelik ilgisi olduğunu göstermektedir. Grafik 1 verileri doğrultusunda Türk müziğine yönelik ilginin arttırımasına daha yoğun faaliyetlere intiyaç duyulduğu söylenebilir. Bu konudaki çabalar desteklenmeli ve Türk müziğine olan ilgi daha da arttırılmalıdır.

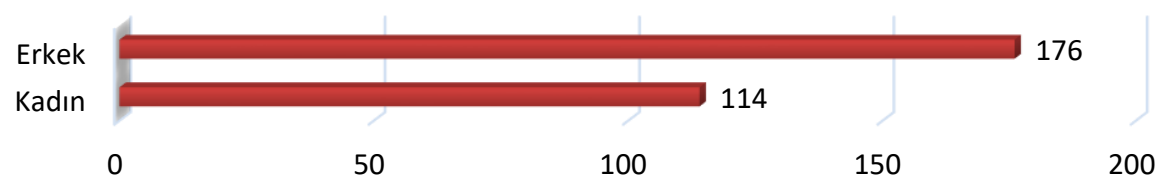

Grafik 2. Cinsiyete Göre Türk Müziği İlgi Durumu

Özengen müzik eğitimi veren kurumlarda Türk Müziği Eğitimi alan kişilerin cinsiyet durumunun sergilendiği grafik 2 incelendiğinde; erkeklerin kadınlara göre nispeten daha yüksek bir oranında konuya ilgi gösterdikleri gözlemlenmektedir. Bu durum, özengen müzik eğitimi alan kadınların popüler müziğe olan daha yoğun ilgisiyle izah edilebilir. Kadın müzikseverlerin popüler müziğe olan ilgisi daha önce gerçekleştirilen bazı araştırılmalarda (imik, 2007: 60) da tespit edilmiştir. Bu konuda yapılması gereken, gelecek nesillerimizi yetiştirecek olan kadınlarımızın (anne ve anne adaylarımızın) Türk müziğine yönelik ilgi düzeyini yükseltecek uygulama ve faaliyetlerin desteklenmesidir.

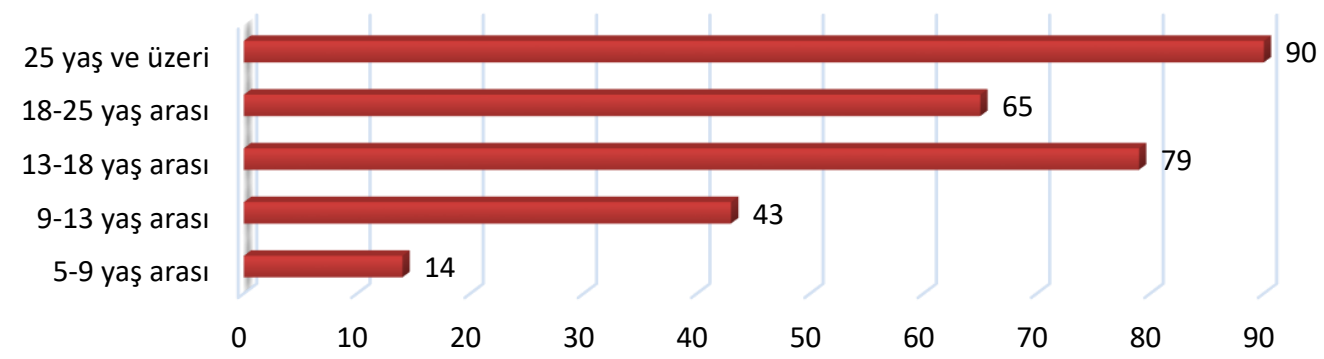

Grafik 3. Yaşa Göre Türk Müziği İlgi Durumu

Grafik 3 incelendiğinde; özengen Türk Müziği eğitimine en yüksek ilgiyi gösteren yaş grubunun 25 ve üzeri örneklemler olduğu gözlemlenmektedir. Konuya yönelik en düşük ilgi grubunun ise 5-9 yaş aralığındaki örneklemler olduğu görülmektedir. Grafik 3 verileri dikkate alınarak tük müziği ilgisinin yaş durumu ile aynı doğrultuda hareket ettiği görülmektedir. Yaş ilerledikçe konuya yönelik ilgili birey sayısında belirgin bir artış gözlemlenmektedir. Konuya yönelik bir diğer yaklaşım ise, özellikle Klasik Türk Müziğinde bulunan nazari özelliklerin popüler müzik eğitimine oranla daha detaylı bilgi gerektirmesi sebebiyle küçük yaşlarda kolay kavranamayabileceğidir. Bu konuda yapılması gereken, Türk müziği eğitimi süreçlerinin genç yaştaki bireylerinde kolaylıkla uygulayabileceği ilgi çekici düzeylerde ele alınmasının önemli olduğunun unutulmamasıdır. Bu sayede Türk müziği sadece ileri yaş bireylerin değil okul öncesi bireylerin de kolaylıkla tercih edebileceği bir süreç haline gelebilecektir. 


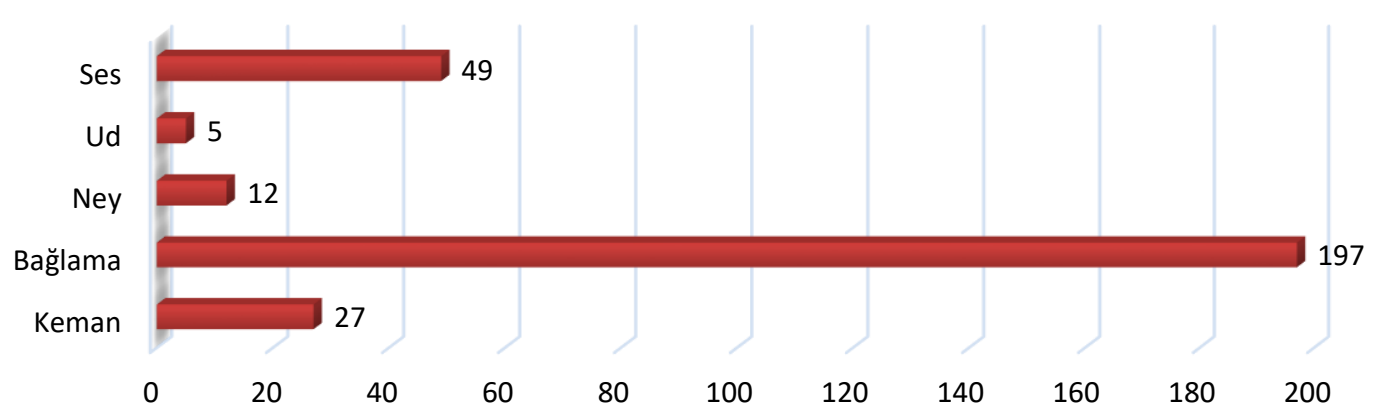

Grafik 4. Türk Müziği Çalgılarına Göre İlgi Durumu

Türk müziği çalgılarına yönelik ilgi durumunun sorgulandığı grafik 4 incelendiğinde özellikle bağlama çalgısına yönelik oldukça yüksek bir oranda ilgi gösterildiği dikkat çekmektedir. Bu durum, bağla çalgısına halkımızın özel bir anlam yüklemesi olarak ifade edilebilir. Zira Türk halk müziği denilince hemen her yöremizde ilk akla gelen çalgımız bağlama ailesidir. Tabloda dikkat çeken bir önemli detay ise, Türk müziği ses eğitimine yönelik yüksek ilgi orandır. Köken itibarı ile bir batı müziği çalgısı olmasına rağmen keman çalgısına yönelik te ciddi bir ilgi mevcuttur. Özellikle perdesiz olmasının verdiği imkânlarla Türk müziğinin kolaylıkla icra ediliyor olabilmesinin bunda büyük etkisi olduğu düşünülebilir. Tabloda yine ney ve ud çalgılarımıza yönelik ilgi düzeyi de yer bulmaktadır. Tablo verileri doğrultusunda özengen Türk müziği eğitimi verilen kurumlarda en çok tercih edilen Türk müziği çalgısının bağlama olduğu söylenebilir. Malatya örnekleminde etken olabilecek bir diğer husus ise, yörede etkisi bulunan ve çoğunlukla bağlama çalgısı ile duyguların ifade edildiği Arguvan müzik kültürüdür.

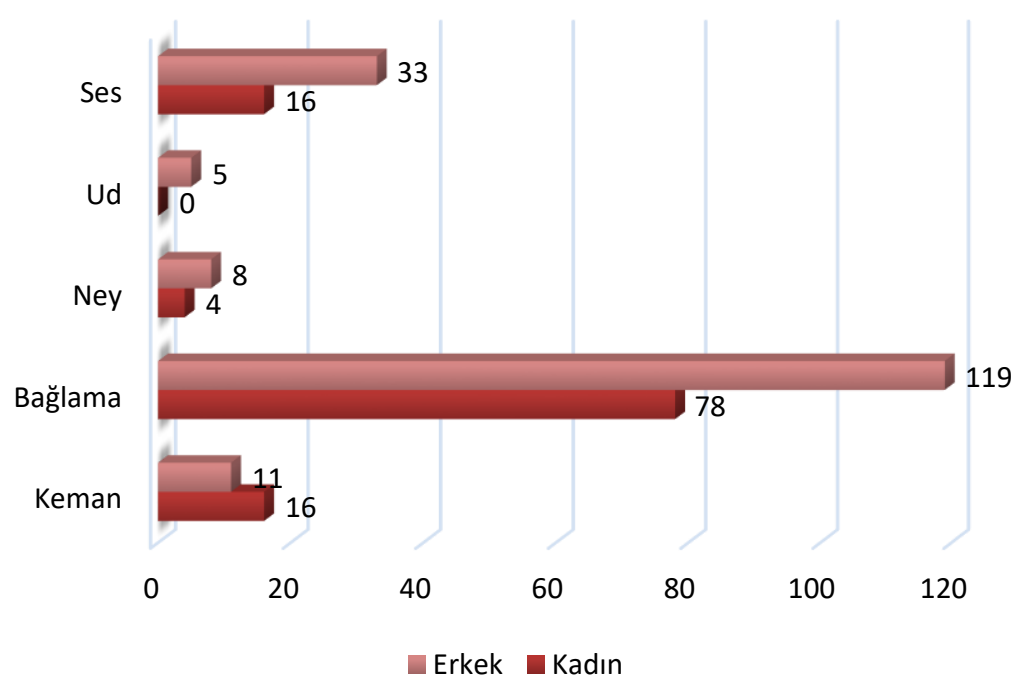

Grafik 5. Cinsiyet Durumuna Göre Türk Müziği Çalgılarına İlgi

Cinsiyet Durumuna Göre Türk Müziği Çalgılarına İlgi durumunun sorgulandığı grafik 5 incelendiğinde özellikle çeşitli çalgılarda cinsiyete durumuna göre ilgi düzeylerinde belirgin bir fark olduğu gözlemlenmektedir. Özellikle bağlama, ses eğitimi, ney ve ud gibi çalgılarda erkek bireylerin kadın bireylere 
oranla daha yoğun bir ilgisinin olduğu görünmesine karşın keman çalgısında ise kadın örneklemelerin erkek örneklemlere göre daha yoğun bir ilgi gösterdiği görülmektedir. Bu durum da, keman çalgısının kadın bireylere daha ilgi çekici geldiği sonucunu çıkarmak mümkündür.

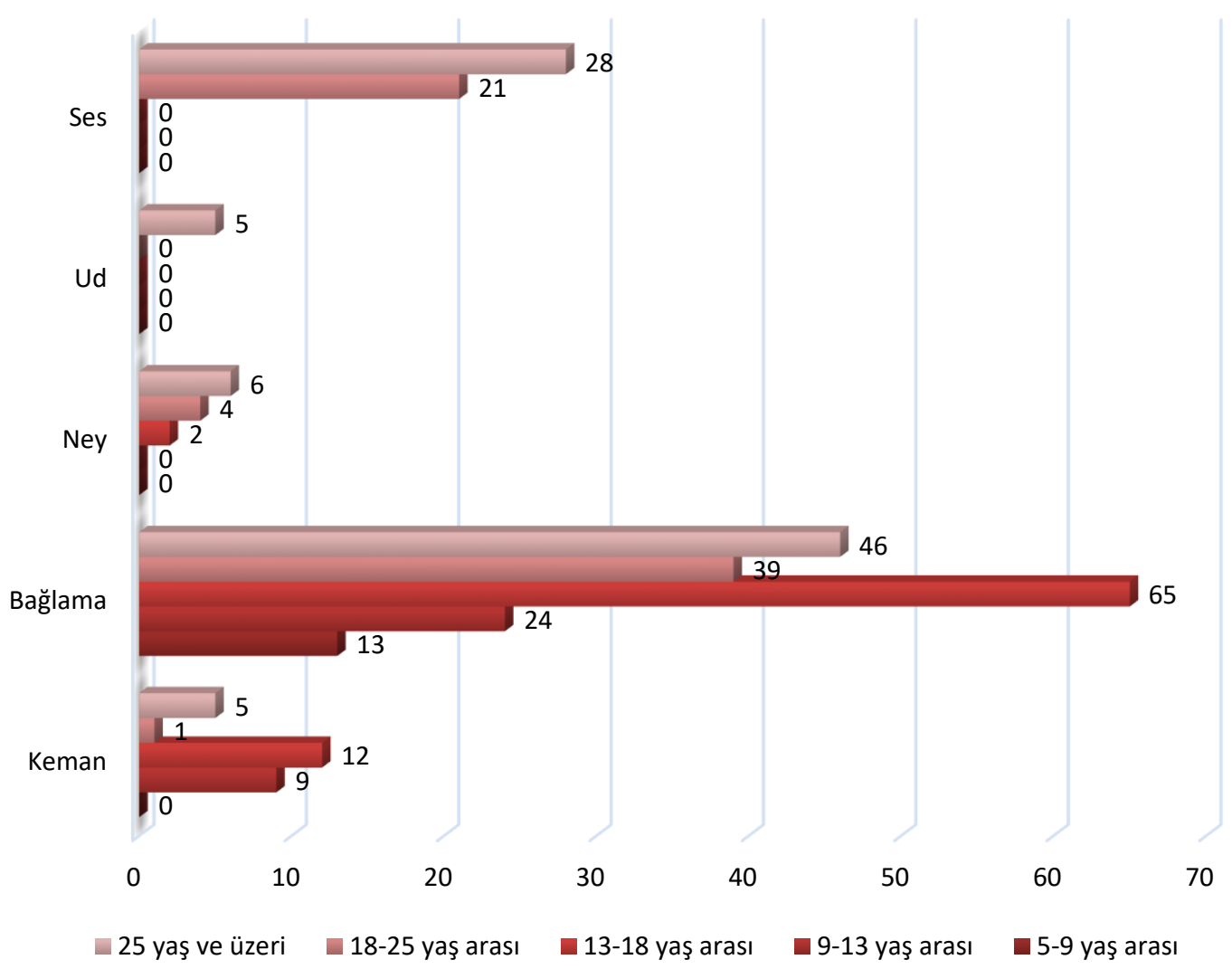

Grafik 6. Yaş Durumuna Göre Türk Müziği Çalgılarına İlgi

Yaş Durumuna Göre Türk Müziği Çalgılarına İlgi düzeyinin sorgulandığı grafik 6 incelendiğinde en dikkat çeken detayın bağlama çalgısına her yaştan bireyin ilgi gösterdiği olacaktır. Bağlama çalgısı dışında kalan diğer çalgılar incelenecek olursa ud çalgısının daha çok orta ve ileri yaş bireyler tarafından tercih edildiği söylenebilir. Keman çalgısı ise daha çok genç yaştaki bireyler tarafından tercih edilmektedir. Ses eğitimi derslerine yönelik ilginin ise daha çok orta ve ileri yaştaki bireylerden geldiği görülmektedir. Bu durum ses eğitimi ve çeşitli cemiyetlerdeki koro faaliyetlerinin bireyler tarafından bir sosyal aktivite olarak görülebileceği şeklinde yorumlanabilir. Ney çalgısına ilginin de genç ve ileri yaşlardaki örneklemlerden geldiği söylenebilir. $\mathrm{Bu}$ durum ise ney çalgısının manevi özelliklerde sergilemesi yönü ile daha ileri yaşlarda beğeni oluşturabileceği seklinde yorumlanabilir. 


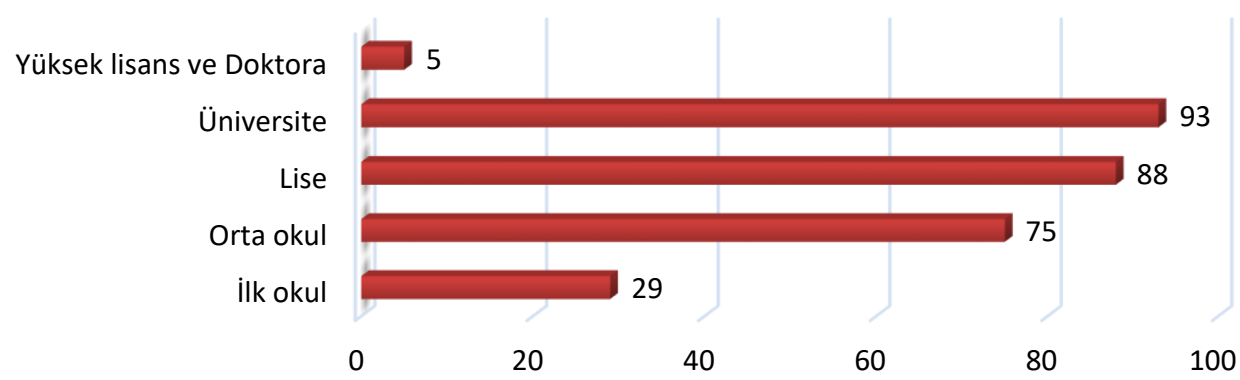

Grafik 7. Eğitim Durumuna Göre Türk Müziğine İlgi

Özengen Türk Müziği eğitimi alan katılımcıların eğitim Durumlarına göre Türk Müziğine İlgilerinin sorgulandığı grafik 7 incelendiğinde en yoğun ilginin sırası ile üniversite ve lise öğrencilerinde geldiği görülmektedir. Ortaokul öğrencilerinin ilgisi de oldukça yoğun bir düzeyde olup ilköğretim öğrencilerinde bu oranda ciddi bir düşüş yaşanmaktadır. Grafikte yer alan eğitim düzeylerinde en düşük katııı lisansüstü eğitim seviyesindeki bireylerdir. Bu durum lisansüstü eğitim seviyesindeki bireylerin ilgisizliğinden ziyade sayı bakımından diğer eğitim gruplarındaki bireylere oranla daha az sayıda olmalarına bağlanabilir. Türk müziği eğitimi süreçlerinin genç yaştaki bireylerinde kolaylıkla uygulayabileceği ilgi çekici düzeylerde ele alınmasının önemli olduğunun unutulmamalıdır. Bu sayede Türk müziği sadece ileri yaş bireylerin değil ilk okul ve okul öncesi bireylerin de kolaylıkla tercih edebileceği bir süreç haline gelebilecektir.

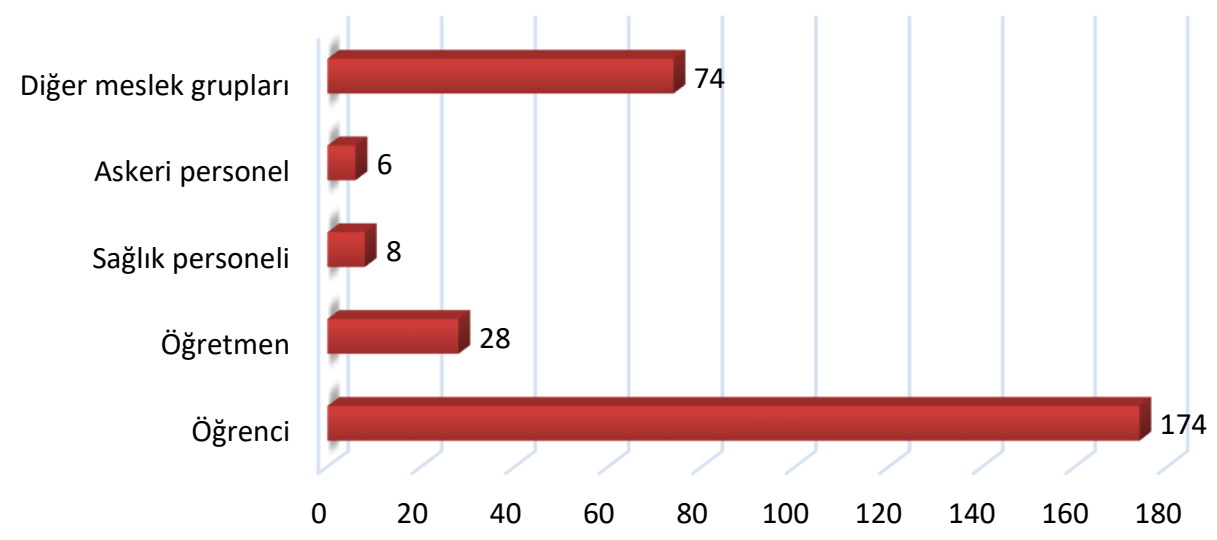

Grafik 8. Mesleki Duruma Göre Türk Müziğine İlgi

Özengen Türk Müziği eğitimi alan katılımcıların meslek dağııımının incelendiği grafik 8 incelendiğinde; öğrenci ve öğretmenlerin yüksek bir oranda katılım sağladıkları görülmektedir. Daha az oranlarda diğer meslek gruplarından da katıımlar mevcuttur. Öğrencilerin bu denli yoğun katıımını sağlayan etkenler arasında ailelerin çocuklarına Türk Müziğini aşılama isteği ve çocukların müziğe olan ilgisi olarak değerlendirilebilir. 


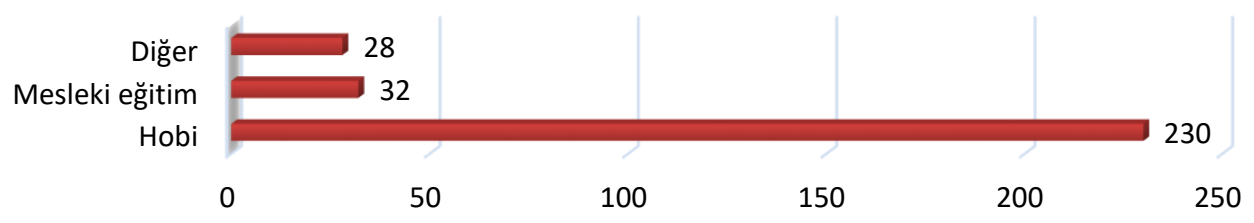

Grafik 9. Türk Müziğine Yönelik İlginin Genel Amacı

Özengen Türk müziğine yönelik ilginin genel amacının sorgulandığı grafik 9 incelendiğinde; özengen müzik eğitimine hobi olarak başladığının belirten kitlenin oldukça büyük bir oranda olduğu görülmektedir. Bu durum, özengen müzik eğitimi sürecinin bireysel bir hobi faaliyeti olarak düşünülmesi gerektiği yönündeki tespiti de teyit etmektedir.

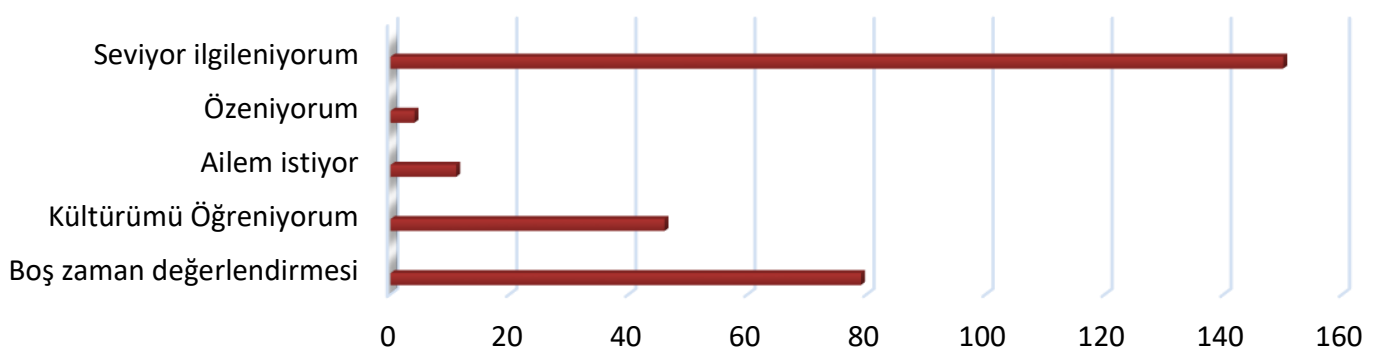

Grafik 10. Türk Müziğine Yönelik İlginin Nedeni

Özengen Türk müziğine yönelik ilginin nedeninin sorgulandığı tablo 10 incelenecek olursa: en yüksek tercih sebebinin seviyor ve ilgileniyorum olduğu görülecektir. Daha sonra boş zaman değerlendirme isteği ve kültürel öğrenme süreci düşüncesi gelmektedir. Bu konuda en düşük cevaplar ailenin isteği ve özenerek geldiğini belirtenlerdir. Grafik 10 verileri doğrultusunda özengen müzik eğitimi isteğinin temelinde müzik sanatına olan ilgi ve sevginin olduğu söylenebilir.

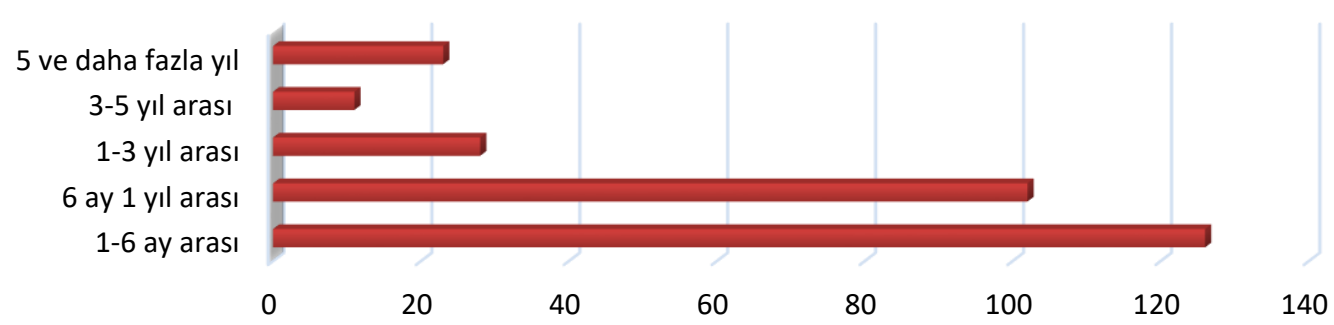

Grafik 11. Türk Müziğine Yönelik Alınan Özengen Müzik Eğitimine Bireysel Devam Süresi

Türk Müziğine yönelik alınan özengen müzik eğitimine bireysel devam süresinin sorgulandığı grafik 11 incelendiğinde en uzun sürenin 6 ay ile sınırlandığı görülmektedir. Bir sonraki yüksek oranlı seçim grubu ise 6ay ile 1 yıl arasında özengen müzik eğitimi alanlardır. Bu konuda 3 yıl ve üzerinde eğitim alan örneklem 
oranı oldukça düşük bir seviyededir. Grafik verileri doğrultusunda özengen müzik eğitiminde bireylerin en yüksek oranda tercih ettiği eğitimi süreci bir yıl ile sınırı kalmaktadır. Uzun süreli müzik eğitimi özengen müzik eğitiminde pek tercih edilmemektedir.

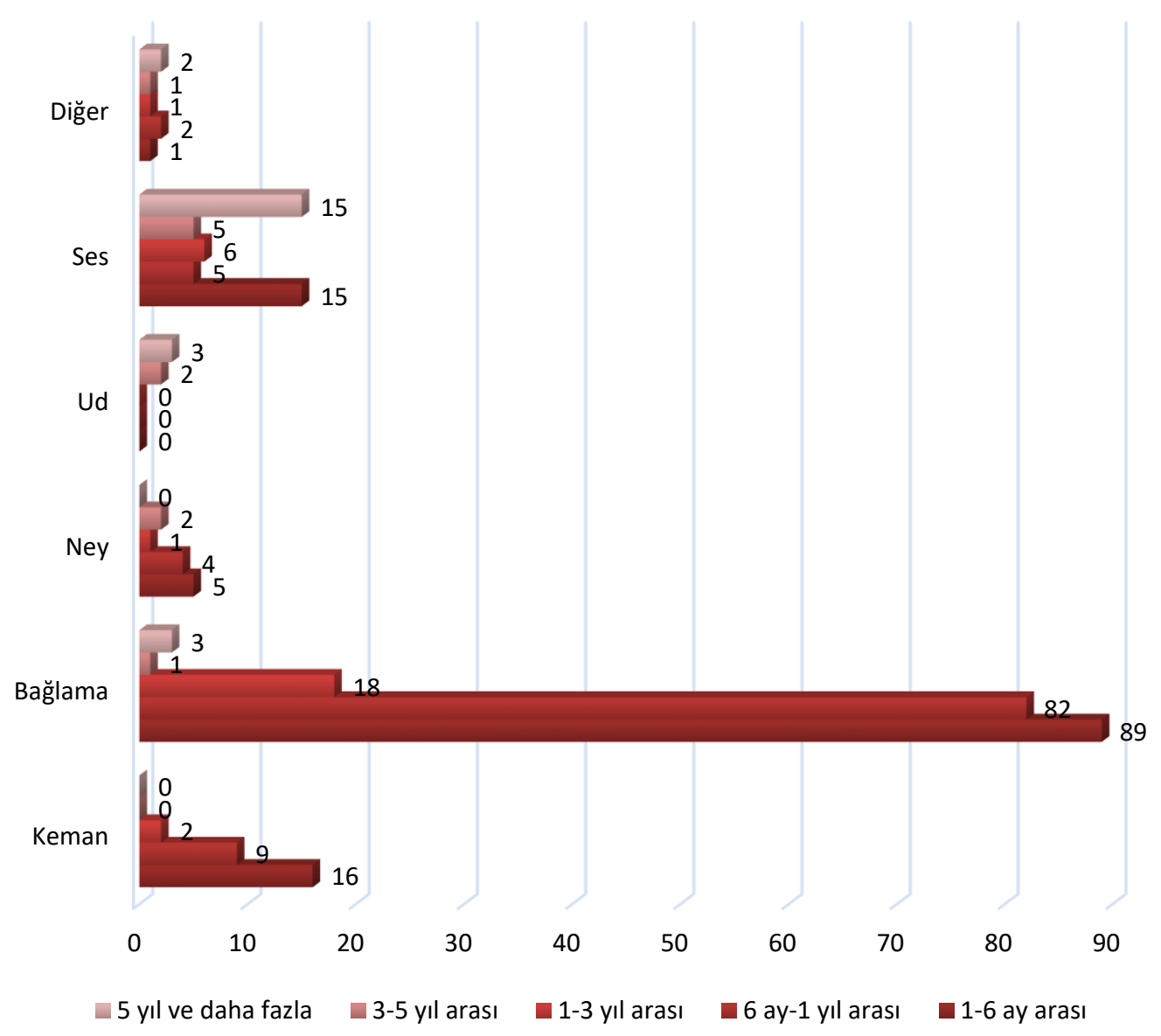

Grafik 12. Türk Müziğine Yönelik Alınan Özengen Eğitime Çalgılara Göre Devam Süresi

Grafik 12incelendiğinde ud ve ses eğitimi derslerine daha uzun süre devam edilmesine rağmen bağlama, keman ve diğer çalgılarda daha kısa süreli bir müzik eğitimi yaklaşımın sergilendiği görülmektedir. özellikle bağlama ve keman eğitiminde uzun süreli müzik eğitimi sürdüren örneklem oranı oldukça düşük seviyededir.

\section{Sonuç ve Öneriler}

Bu bölümde araştırma sürecinde elde edilen sonuçlar ve bu sonuçlar doğrultusunda geliştirilen öneriler maddeler halinde sıralanmaktadır.

- Özengen müzik eğitimi sürecinde Türk müziğine ilgi düzeyinin istenilen seviyede olmadığı görülmektedir. Bu nedenle Türk Müziğine olan ilginin arttırımasına yönelik daha yoğun faaliyetlere intiyaç duyulmaktadır. Özellikle genç yaştaki bireylerin Türk müziği alanında yeterli düzeyde bilgi sahibi olması oldukça önemli görülmedir. Kendi öz müzik kültürümüzden uzaklaşma durumu, çeşitli ilgi çekici ve teşvik edici yollarla önlenmelidir. 
- Erkeklerin kadınlara göre nispeten daha yüksek bir oranında konuya ilgi gösterdikleri gözlemlenmektedir. Bu durum, özengen müzik eğitimi alan kadınların popüler müziğe olan daha yoğun ilgisiyle izah edilebilir. Özellikle gelecek nesillerimizi yetiştirecek olan annelerimizin Türk müziğinden uzaklaşmaması sağlanmalıdır. Özellikle ev hanımlarının ilgisini çekecek Türk müziğine yönelik TV ve Radyo programları onların ilgisini çekecek biçimde hazırlanmalıdır.

- Özengen Türk Müziği eğitimine en yüksek ilgiyi gösteren yaş grubunun 25 ve üzeri örneklemler olduğu gözlemlenmektedir. Bu durum, özellikle 25 yaş altındaki genç bireylerin farklı müzik kültürlerinin etkisinde olduğunun da bir göstergesi olarak algılanabilir. Türk müziği sadece orta ve ileri yaş dinleyicilerin değil aynı zamanda genç dinleyicilerinde ilgisini çekebilecek bir şekilde sunulmalı ve bu yönde çeşitli projeler hazırlanarak kamu ve özel kuruluşlarca desteklenmelidir.

- Türk müziği çalgılarına yönelik ilgi durumu incelendiğinde, özellikle bağlama çalgısına yönelik oldukça yüksek bir oranda ilgi gösterildiği görülmektedir. Bu durum, bağlama çalgısına halkımızın özel bir anlam yüklemesi olarak ifade edilebilir. Bu durum oldukça olumlu görülse de diğer çalgılarımızın da bu seviyede tanınmaya ve sevilmeye intiyaç duyduğu unutulmamalıdır. Bağlama çalgısı ile yakalanan başarı durum kendi kültürümüze ait diğer çalgılarda da hedeflenmeli ve bu yönde etkili ve sonuç alınabilecek çabalar (çalgı tanıtım programları, uygun fiyatı ve temin edilebilir çalgılar, ücretsiz dersler vb.) sarf edilmelidir.

- Özellikle bağlama, ses eğitimi, ney ve ud gibi çalgılarda erkek bireylerin kadın bireylere oranla daha yoğun bir ilgisinin olduğu görünmesine karşın keman çalgısında ise kadın örneklemelerin daha yoğun bir ilgi gösterdiği görülmektedir. Araştırma verileri doğrultusunda, keman çalgısının kadın müzik severlere daha ilgi çekici geldiği söylenebilir.

- Yaş Durumuna Göre Türk Müziği Çalgılarına İlgi düzeyi incelendiğinde en dikkat çeken detay bağlama çalgısına her yaştan bireyin ilgi gösterdiğidir. Bağlama çalgısı dışında kalan diğer çalgılardan ud çalgısının ise daha çok orta ve ileri yaş bireyler tarafından tercih edildiği söylenebilir. Keman çalgısı ise daha çok genç yaştaki bireyler tarafından tercih edilmektedir. Ses eğitimi derslerine yönelik ilginin ise daha çok orta ve ileri yaştaki bireylerden geldiği görülmektedir.

- Özengen Türk Müziği eğitimine en yoğun ilginin sırası ile üniversite ve lise öğrencilerinde geldiği görülmektedir. Ortaokul öğrencilerinin ilgisi ise az da olsa yeterli görülebilecek seviyede olup, ilköğretim öğrencilerinde bu oranda ciddi bir düşüş yaşanmaktadır. Müzik beğenisi ve sevgisinin küçük yaşlarda oluşabileceği düşünüldüğünde bu yaşlarda evrensel müzik eğitiminin yanı sıra kendi öz müzik kültürümüze yönelik tanıtım çabalarının da bulunmasının geleceğe yönelik olumlu sonuçlar doğurabileceği unutulmamalıdır.

- Araştırma sonuçlarından biri de özengen müzik eğitimi sürecinin bireysel bir hobi faaliyeti olarak görüldüğü yönündeki düşünceyi de teyit etmesidir. Katıııcıların büyük bölümü özengen müzik eğitimini bir hobi faaliyeti olarak görmektedir.

- Özengen müzik eğitiminde bireylerin en yüksek oranda tercih ettiği müzik eğitimi süreci genelde bir yıl ile sınırı kalmaktadır. Uzun süreli müzik eğitimi süreçlerinin özengen müzik eğitimi öğrencileri tarafından pek tercih etmediği görülmektedir. Müzik eğitiminde başarının ancak istikrarlı bir yaklaşımla 
gerçekleşebileceği düşünülerek, bu kısa olarak nitelendirilebilecek süreçler başarı elde edebilmek adına daha uzun bir hale dönüşme yönünde teşvik edilmelidir.

\section{Kaynaklar:}

1. Akbulut, E. (1999, Mayıs). Çalgı eğitiminde davranışların önemi, Pamukkale Üniversitesi Eğitim Sempozyumu, Denizli

2. Akyüz, Y. (2006). Türk Eğitim Tarihi M.Ö. 1000-M.S. 2006. (10. Baskı). Ankara: Pegem A Yayıncılık.

3. Bloom, B. (1979). İnsan Nitelikleri ve Okulda Öğrenme. (Çev. D. Ali Özçelik). Ankara: Milli Eğitim Basımevi.

4. Çetin, T. (2002). Sanat Eğitiminin Gerekliliği Üstüne. (08-10 Mayıs). Sanat Eğitimi Sempozyumu, Gazi Üniversitesi, Ankara.

5. Çilden, Ş. (2001). Müzik, çocuk gelişimi ve öğrenme. G.Ü. Gazi Eğitim Fakültesi Dergisi, Cilt 21, Sayı 1, s. 1-8, Web: http//gefad.gazi.edu.tr adresinden 20 Şubat 2009 'de alınmıştır.

6. Davidson J.-Jordan N. (2007). Private teaching, private learning- An explotarion of music instrument learning in the private studio, junior and senior conservatories. International Handbook of Research in Arts Education, s. 729-744. (Web: http://springerlink.com/content adresinden 16 Haziran 2015'de alınmıştır).

7. Deverich, R. K. (2006). How did they learn. Web: http//www. violinonline.com adresinden12 Temmuz 2015'de alınmıştır

8. Ersoy, A. (1985). Gençliğin Sanat Eğitimi. 5. İstanbul Sanat Bayramı. M.S.Ü. Sanat ve Gençlik Sempozyumu Bildirisi, İstanbul.

9. Ertürk, S. (1972). Eğitimde Program Geliştirme. (7. Basım). Ankara: Meteksan Yayınları.

10. Finkelstein, S. (2000). Müzik Neyi Anlatır. (Çev: M. Halim Spatar). (3. Basım). İstanbul: Kaynak Yayınları.

11. Gençaydın, Z. (2002). Sanat Eğitimcisi Yetiştirmede G.E.E. Resim-İş Bölümünün Yeri ve Bugünkü Durumu Üstüne. (08-10 Mayıs). Sanat Eğitimi Sempozyumu, Gazi Üniversitesi, Ankara.

12. İmik, Ü. (2007) Sosyal Statünün Müzik Beğenisine Etkisi, İnönü üniversitesi Sosyal Bilimler Enstitüsü Yayımlanmamış Yüksek Lisans Tezi, Malatya.

13. Kırışoğlu, O. T. (1991). Sanatta Eğitim. Ankara: TED Yayınları.

14. Özsoy, V. (2003). Görsel Sanatlar Eğitimi. Ankara: Gündüz Eğitim ve Yayıncılık

15. Özsoy, V. (2007). Görsel Sanatlar Eğitimi. (2. Baskı). Ankara: Gündüz Eğitim ve Yayıncılık.

16. Say, A. (1998). Türkiye'nin Müzik Atlası. Ankara: Borusan Yayıncılık

17. San, İ. (1985). Gençliğin Sanat Eğitimi. 5. İstanbul Sanat Bayramı M.S.Ü. Sanat ve Gençlik Sempozyumu Bildirisi, İstanbul.

18. Tezcan, M. (1996). Eğitim Sosyolojisi. Ankara: Gelişim Yayıncılık

19. Uçan, A. (2005). Müzik Eğitimi. Ankara: Evrensel Müzikevi.

20. Uçan, A. (1996). İnsan ve Müzik, İnsan ve Sanat Eğitimi. (2. Basım). Ankara: Müzik Ansiklopedisi Yayınları. 
21. Uçan, A. (1997). Müzik Eğitimi-Temel Kavramlar- İlkeler- Yaklaşımlar. (2. Basım).

22. Ankara: Müzik Ansiklopedisi Yayınları

23. Ürün, T. (2015). Karşılaştırmalı Tonal ve Makamsal Dizi Öğretiminin Silahlı Kuvvetler Bando Okulları Öğrencilerinin Bilişsel Gelişimlerine Etkisi. Yüksek Lisans Tezi: Afyonkarahisar.

24. Webern, A. (1998). Yeni Müziğe Doğru. (Çev. Ali Bucak). (2. Basım). İstanbul: Pan Yayıncılık. 